\title{
Synthesis of Medium Ring Nitrogen Heterocycles via a Tandem Copper- Catalyzed C-N Bond Formation-Ring Expansion Process
}

\author{
Artis Klapars, Sean Parris, Kevin W. Anderson and Stephen L. Buchwald* \\ Department of Chemistry, Massachusetts Institute of Technology, Cambridge, MA 02139
}

\section{Supporting Information}

\section{General Considerations}

Reagents: $\mathrm{CuI}$ was purchased from Strem Chemical Co. and used without further purification. $N, N^{\prime}$-dimethylethylenediamine, 2-azetidinone, and 2-(2-bromophenyl)ethylamine were purchased from Aldrich. 2-Bromobenzylamine was purchased from Alfa Aesar and distilled under vacuum before use. Powdered $\mathrm{K}_{2} \mathrm{CO}_{3}$ was used directly from the bottle that was bought from Aldrich. Toluene and THF were purchased from J. T. Baker in CYCLE-TAINER ${ }^{\circledR}$ solvent delivery kegs, which were vigorously purged with argon for $2 \mathrm{~h}$, and further purified by passing the solvent through two packed columns of neutral alumina and copper (II) oxide under argon pressure. Anhydrous dioxane was purchased from Aldrich in Sure/Seal ${ }^{\mathrm{TM}}$ bottles and used without further purification. All other reagents were purchased from Alfa Aesar or Aldrich, and used without further purification. Flash column chromatography was performed with EM Science silica gel 60 (230-400 mesh).

Analytical methods: All reactions were carried out under an argon atmosphere in oven-dried Schlenk tubes. IR spectra were obtained by placing neat samples directly on the DiComp probe

of an ASI REACTIR in situ IR instument. ${ }^{1} \mathrm{H}$ NMR and ${ }^{13} \mathrm{C}$ NMR spectra were recorded on a Bruker $400 \mathrm{MHz}$ with chemical shifts reported in ppm relative to the internal standard tetramethylsilane. Elemental analyses were performed by Atlantic Microlabs, Norcross, GA. Gas chromatography analyses were performed on a Hewlett Packard 5890 instrument with a FID 
detector and a Hewlett Packard 25 m x 0.2 mm i.d. HP-5 capillary column or a Hewlett Packard 6890 instrument with a FID detector and a Hewlett Packard 10 m x 0.1 mm i.d. HP-1 column. Yields refer to isolated yields of compounds greater than $95 \%$ purity as determined by capillary gas chromatography (GC), and proton Nuclear Magentic Resonance spectroscopy ( ${ }^{1} \mathrm{H}$ NMR) analysis. Yields for the preparation of starting materials refer to a single experiment whereas those reported in Tables 1 and 2 are an average of two or more runs. The procedures described in this section are representative; thus, the yields may differ slightly from those given in Tables 1 and 2. All new compounds were further characterized by elemental analysis or HRMS. 


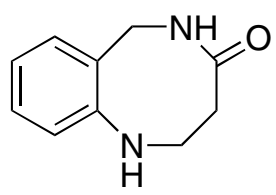

2,3,5,6-Tetrahydro-1 $H$-benzo[b][1,5]diazocin-4-one (Table 1, entry 1). A Schlenk tube was charged with $\mathrm{CuI}(9.6 \mathrm{mg}, 0.050 \mathrm{mmol}, 5.0 \mathrm{~mol} \%)$, 2-azetidinone (177 mg, $1.20 \mathrm{mmol}), \mathrm{K}_{2} \mathrm{CO}_{3}$ (280 mg, $2.03 \mathrm{mmol})$, evacuated and backfilled with argon. 2-Bromobenzylamine (125 $\mu \mathrm{L}, 1.00$ mmol) and toluene $(1.0 \mathrm{~mL})$ were added under argon. The Schlenk tube was sealed with a Teflon valve and the reaction mixture was stirred at $110{ }^{\circ} \mathrm{C}$ for $24 \mathrm{~h}$ in a preheated oil bath. After the resulting green-brown suspension was allowed to reach room temperature, dodecane (46 $\mu \mathrm{L}$, internal $\mathrm{GC}$ standard) and $\mathrm{CH}_{2} \mathrm{Cl}_{2}(3 \mathrm{~mL})$ were added, and the supernatant solution was analyzed by GC to indicate $>99 \%$ conversion of the aryl bromide starting material. The reaction mixture was filtered through a silica gel plug $(0.5 \times 0.5 \mathrm{~cm})$ eluting with $10: 1 \mathrm{CH}_{2} \mathrm{Cl}_{2}-\mathrm{MeOH}(50$ $\mathrm{mL}$ ), the filtrate was concentrated, and the residue was purified by column chromatography on silica gel $\left(\mathrm{CH}_{2} \mathrm{Cl}_{2}-\mathrm{MeOH} 20: 1\right)$ to provide the desired product as a pale yellow solid (167 $\mathrm{mg}$, 95\% yield). Mp 109-110 ${ }^{\circ} \mathrm{C} .{ }^{1} \mathrm{H}$ NMR $\left(400 \mathrm{MHz}, \mathrm{CDCl}_{3}\right): \delta$ 7.16-7.09 (m, 2H), $6.90(\mathrm{td}, \mathrm{J}=$ 7.6, 1.2 Hz, 1H), 6.76 (d, J = 7.6 Hz, 1H), 6.40 (br s, 1H), 4.37 (d, J = 7.7 Hz, 2H), 3.94 (br s, $1 \mathrm{H}), 3.40-3.33(\mathrm{~m}, 2 \mathrm{H}), 2.87-2.81(\mathrm{~m}, 2 \mathrm{H}) .{ }^{13} \mathrm{C} \mathrm{NMR}\left(100 \mathrm{MHz}, \mathrm{CDCl}_{3}\right): \delta 176.1,148.9,130.9$, 129.7, 129.2, 122.3, 121.5, 45.7, 45.3, 39.1. IR (neat, $\mathrm{cm}^{-1}$ ): 3319, 1653, 1604, 1485, 1409, 1093, 756. Anal. Calcd for $\mathrm{C}_{10} \mathrm{H}_{12} \mathrm{~N}_{2} \mathrm{O}$ : C, 68.16; H, 6.86. Found: C, 68.42; H, 6.94.

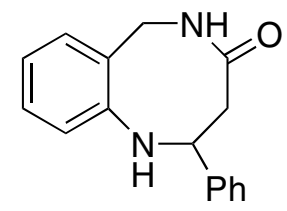

2-Phenyl-2,3,5,6-tetrahydro-1H-benzo[b][1,5]diazocin-4-one (Table 1, entry 2). A Schlenk tube was charged with $\mathrm{CuI}(9.6 \mathrm{mg}, 0.050 \mathrm{mmol}, 5.0 \mathrm{~mol} \%)$, (rac)-4-phenyl-2-azetidinone ${ }^{1}$ (177 $\mathrm{mg}, 1.20 \mathrm{mmol}), \mathrm{K}_{2} \mathrm{CO}_{3}(280 \mathrm{mg}, 2.03 \mathrm{mmol})$, evacuated and backfilled with argon. $N, N^{\prime}-$ Dimethylethylenediamine (11 $\mu \mathrm{L}, 0.10 \mathrm{mmol}, 10 \mathrm{~mol} \%)$, 2-bromobenzylamine (125 $\mu \mathrm{L}, 1.00$ mmol), and toluene $(1.0 \mathrm{~mL})$ were added under argon. The Schlenk tube was sealed with a Teflon valve and the reaction mixture was stirred at $110^{\circ} \mathrm{C}$ for $25 \mathrm{~h}$ in a preheated oil bath. The resulting yellow suspension allowed to reach room temperature, transferred to a solution of $30 \%$

\footnotetext{
${ }^{1}$ Prepared from chlorosulfonyl isocyanate and styrene in $16 \%$ yield according to: Forró, E.; Füllöp, F. Tetrahedron: Assym. 2001, 12, 2351.
} 
aq $\mathrm{NH}_{3}(5 \mathrm{~mL})$ in water $(20 \mathrm{~mL})$, and extracted with ethyl acetate $(3 \times 75 \mathrm{~mL})$. The combined organic layers were dried $\left(\mathrm{Na}_{2} \mathrm{SO}_{4}\right)$ and concentrated by rotary evaporation. The residue was dissolved in hot ethyl acetate $(\sim 10 \mathrm{~mL})$. To this solution was added hot hexane $(\sim 10 \mathrm{~mL})$, and the product was allowed to crystallize from the solution in the fridge overnight. The supernatant solution containing some yellow, gelatinous precipitate was decanted, and the white crystals remaining in the flask were dried under vacuum to provide the desired product $(230 \mathrm{mg}, 92 \%$ yield). Mp 170-171 ${ }^{\circ} \mathrm{C} .{ }^{1} \mathrm{H}$ NMR $\left(400 \mathrm{MHz}, \mathrm{CDCl}_{3}\right): \delta 7.45-7.30(\mathrm{~m}, 5 \mathrm{H}), 7.20-7.08(\mathrm{~m}, 2 \mathrm{H})$, $6.97(\mathrm{t}, J=7.6 \mathrm{~Hz}, 1 \mathrm{H}), 6.75(\mathrm{~d}, J=7.6 \mathrm{~Hz}, 1 \mathrm{H}), 6.33(\mathrm{br} \mathrm{s}, 1 \mathrm{H}), 4.56(\mathrm{dd}, J=15.4,8.6 \mathrm{~Hz}, 1 \mathrm{H})$, $4.41(\mathrm{dd}, J=15.4,6.8 \mathrm{~Hz}, 1 \mathrm{H}), 4.26(\mathrm{dd}, J=9.8,2.3 \mathrm{~Hz}, 1 \mathrm{H}), 3.71(\mathrm{~s}, 1 \mathrm{H}), 3.30$ (dd, $J=14.0$, $9.8 \mathrm{~Hz}, 1 \mathrm{H}), 2.94(\mathrm{dd}, J=14.0,2.3 \mathrm{~Hz}, 1 \mathrm{H}) .{ }^{13} \mathrm{C} \mathrm{NMR}\left(100 \mathrm{MHz}, \mathrm{CDCl}_{3}\right): \delta 174.6,147.4$, 144.9, 130.3, 129.2, 128.9, 128.0, 126.2, 122.7, 122.5, 60.7, 45.8, 45.2. IR (neat, $\mathrm{cm}^{-1}$ ): 3293, 1654, 1472, 1457, 757, 731, 699. Anal. Calcd for $\mathrm{C}_{16} \mathrm{H}_{16} \mathrm{~N}_{2} \mathrm{O}$ : C, 76.16; H, 6.39. Found: C, $76.20 ; \mathrm{H}, 6.45$.

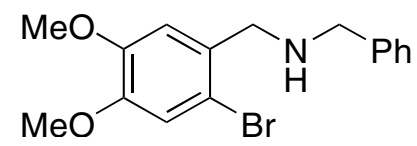

1-Bromo-2-benzylaminomethyl-4,5-dimethoxybenzene. A solution of 2-bromobenzaldehyde $(2.37 \mathrm{~g}, 9.67 \mathrm{mmol})$ and benzylamine $(1.06 \mathrm{~mL}, 9.70 \mathrm{mmol})$ in toluene $(30 \mathrm{~mL})$ was refluxed in a Dean-Stark apparatus for $15 \mathrm{~min}$. The reaction mixture was allowed to reach room temperature and then concentrated by rotary evaporation. The solid residue was suspended in $\mathrm{MeOH}(10$ $\mathrm{mL}$ ), the suspension was cooled to $0^{\circ} \mathrm{C}$ (water-ice bath), and solid $\mathrm{NaBH}_{4}$ (735 mg, $19.4 \mathrm{mmol}$ ) was added in several portions over 15 min (caution: hydrogen gas evolution). The cooling bath was removed and the suspension was stirred at room temperature for $2 \mathrm{~h}$. The reaction mixture was poured into water $(50 \mathrm{~mL})$ and extracted with $\mathrm{CH}_{2} \mathrm{Cl}_{2}(3 \times 50 \mathrm{~mL})$. The combined organic layers were dried $\left(\mathrm{Na}_{2} \mathrm{SO}_{4}\right)$, concentrated by rotary evaporation, and the residue was purified by column chromatography on silica gel (hexane-ethyl acetate 3:2 followed by ethyl acetate). Fractions 11-30 were concentrated and the residue was further purified by column chromatography on silica gel (hexane-ethyl acetate- $\mathrm{Et}_{3} \mathrm{~N} 30: 10: 1$ ) to provide the desired product as a colorless, viscous oil (1.82 $\mathrm{g}, 56 \%$ yield). ${ }^{1} \mathrm{H}$ NMR (400 $\left.\mathrm{MHz}, \mathrm{CDCl}_{3}\right): \delta 7.38-7.23(\mathrm{~m}$, 5H), $7.01(\mathrm{~s}, 1 \mathrm{H}), 6.94(\mathrm{~s}, 1 \mathrm{H}), 3.86(\mathrm{~s}, 3 \mathrm{H}), 3.85(\mathrm{~s}, 3 \mathrm{H}), 3.82(\mathrm{~s}, 2 \mathrm{H}), 3.80(\mathrm{~s}, 2 \mathrm{H}), 1.75(\mathrm{~s}, 1 \mathrm{H})$. ${ }^{13} \mathrm{C}$ NMR $\left(100 \mathrm{MHz}, \mathrm{CDCl}_{3}\right): \delta 148.6,148.4,140.2,131.3,128.4,128.2,127.0,115.6,113.8$, 113.2, 56.2, 56.0, 53.1, 52.9. IR (neat, $\mathrm{cm}^{-1}$ ): 3338, 1602, 1504, 1453, 1438, 1382, 1260, 1209, 
1160, 1030, 798, 739, 699. HRMS-EI calcd for $\mathrm{C}_{16} \mathrm{H}_{18} \mathrm{BrNO}_{2}\left(\mathrm{M}^{+}\right), 335.0515$ and 337.0494; found, 335.0528 and 337.0504 .

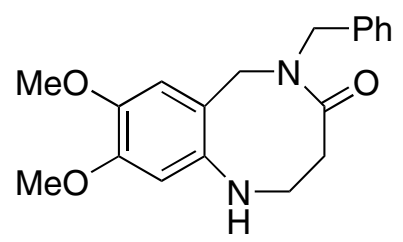

\section{5-Benzyl-8,9-dimethoxy-2,3,5,6-tetrahydro-1H-benzo[b][1,5]diazocin-4-one (Table 1, entry}

3). A Schlenk tube was charged with $\mathrm{CuI}(9.6 \mathrm{mg}, 0.050 \mathrm{mmol}, 5.0 \mathrm{~mol} \%)$, 2-azetidinone (86 $\mathrm{mg}, 1.21 \mathrm{mmol}), \mathrm{K}_{2} \mathrm{CO}_{3}(280 \mathrm{mg}, 2.03 \mathrm{mmol})$, evacuated and backfilled with argon. N,N'Dimethylethylenediamine (11 $\mu \mathrm{L}, 0.10 \mathrm{mmol}, 10 \mathrm{~mol} \%)$, 1-bromo-2-benzylaminomethyl-4,5dimethoxybenzene $(225 \mu \mathrm{L}, 1.00 \mathrm{mmol})$, and toluene $(1.0 \mathrm{~mL})$ were added under argon. The Schlenk tube was sealed with a Teflon valve and the reaction mixture was stirred at $110{ }^{\circ} \mathrm{C}$ for $22 \mathrm{~h}$ in a preheated oil bath. The resulting tan-green suspension was allowed to cool to room temperature, transferred to a solution of $30 \%$ aq $\mathrm{NH}_{3}(5 \mathrm{~mL})$ in water $(20 \mathrm{~mL})$, and extracted with $\mathrm{CH}_{2} \mathrm{Cl}_{2}(4 \times 15 \mathrm{~mL})$. The combined organic layers were dried $\left(\mathrm{Na}_{2} \mathrm{SO}_{4}\right)$, concentrated by rotary evaporation, and the residue was purified by column chromatography on silica gel $\left(\mathrm{CH}_{2} \mathrm{Cl}_{2}-\mathrm{MeOH}\right.$ 20:1). Fractions 14-24 were concentrated and the solid residue was recrystallized from ethyl acetate $(\sim 5 \mathrm{~mL})$ to provide the desired product as white, cotton-like needles (276 mg, 85\% yield from two crops). Mp 167-168 ${ }^{\circ} \mathrm{C} .{ }^{1} \mathrm{H}$ NMR (400 MHz, $\mathrm{CDCl}_{3}$ ): $\delta$ 7.40-7.25 (m, 5H), 6.53 (s, 1H), 6.37 (s, 1H), 4.59 (s, 2H), 4.30 (s, 2H), $3.83(\mathrm{~s}, 3 \mathrm{H}), 3.80$ (s, $3 \mathrm{H}), 3.76$ (br s, $1 \mathrm{H}), 3.37$ (br m, 2H), 3.04-2.96 (m, 2H). ${ }^{13} \mathrm{C} \mathrm{NMR} \mathrm{(100} \mathrm{MHz,} \mathrm{CDCl}_{3}$ ): $\delta$ 173.0, 149.2, 143.7, 143.1, 137.4, 128.6, 128.1, 127.3, 119.0, 115.2, 105.6, 56.6, 55.9, 48.7, 47.6, 45.8, 40.0. IR (neat, $\mathrm{cm}^{-1}$ ): 3348, 1632, 1495, 1521, 1466, 1453, 1268, 1222, 1208, 1164, 1128, 728. Anal. Calcd for $\mathrm{C}_{19} \mathrm{H}_{22} \mathrm{~N}_{2} \mathrm{O}_{3}$ : C, 69.92; H, 6.79. Found: C, 69.69; H, 6.78.

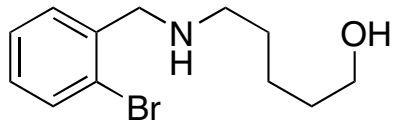

1-Bromo-2-(5-hydroxy-1-pentylaminomethyl)benzene. A solution of 2-bromobenzaldehyde $(1.0 \mathrm{~mL}, 8.6 \mathrm{mmol})$ and 5-amino-1-pentanol $(0.998 \mathrm{~g}, 9.50 \mathrm{mmol})$ in toluene $(10 \mathrm{~mL})$ in a 100 $\mathrm{mL}$ round bottom flask was heated to reflux over $5 \mathrm{~min}$. The mixture was allowed to reach room temperature and concentrated by rotary evaporation. The residue was dissolved in $\mathrm{MeOH}(5$ $\mathrm{mL}$ ), the solution was cooled to $0{ }^{\circ} \mathrm{C}$ (water-ice bath), and solid $\mathrm{NaBH}_{4}(0.980 \mathrm{mg}, 25.9 \mathrm{mmol})$ 
was added in several portions over 15 min (caution: hydrogen gas evolution). The resulting white suspension was stirred at $0{ }^{\circ} \mathrm{C}$ for $15 \mathrm{~min}$, then the cooling bath was removed and the suspension was stirred at room temperature for $2 \mathrm{~h}$. The reaction mixture was poured into water (100 mL) and extracted with $\mathrm{CH}_{2} \mathrm{Cl}_{2}(4 \times 50 \mathrm{~mL})$. The combined organic layers were dried $\left(\mathrm{Na}_{2} \mathrm{SO}_{4}\right)$ and concentrated by rotary evaporation. The residue was purified by column chromatography on silica gel $\left(\mathrm{CH}_{2} \mathrm{Cl}_{2}\right.$ (saturated with $30 \%$ aq $\left.\left.\mathrm{NH}_{3}\right)-\mathrm{CH}_{2} \mathrm{Cl}_{2}-\mathrm{MeOH} 10: 20: 1\right)$ to provide the desired product as a colorless oil $\left(2.10 \mathrm{~g}, 90 \%\right.$ yield). ${ }^{1} \mathrm{H} \mathrm{NMR}\left(400 \mathrm{MHz}, \mathrm{CDCl}_{3}\right)$ : $\delta 7.53(\mathrm{dd}, J=7.8,1.5 \mathrm{~Hz}, 1 \mathrm{H}), 7.37(\mathrm{dd}, J=7.8,1.5 \mathrm{~Hz}, 1 \mathrm{H}), 7.27(\mathrm{td}, J=7.8,1.5 \mathrm{~Hz}, 1 \mathrm{H})$, $7.11(\mathrm{td}, J=7.8,1.5 \mathrm{~Hz}, 1 \mathrm{H}), 3.85(\mathrm{~s}, 2 \mathrm{H}), 3.61(\mathrm{t}, J=6.5 \mathrm{~Hz}, 2 \mathrm{H}), 2.63(\mathrm{t}, J=7.0 \mathrm{~Hz}, 2 \mathrm{H}), 1.81$ (br s, 2H), 1.62-1.50 (m, 4H), 1.47-1.36 (m, 2H). ${ }^{13} \mathrm{C}$ NMR (100 MHz, $\left.\mathrm{CDCl}_{3}\right): \delta 139.2,132.7$, 130.3, 128.5, 127.4, 123.9, 62.5, 53.8, 49.0, 32.5, 29.7, 23.4. IR (neat, $\mathrm{cm}^{-1}$ ): 3301, 1440, 1106, 1056, 1025, 751. HRMS-EI calcd for $\mathrm{C}_{12} \mathrm{H}_{18} \mathrm{BrNO}\left(\mathrm{M}+\mathrm{H}^{+}\right), 272.0644$ and 274.0623; found, 272.0658 and 274.0640 .

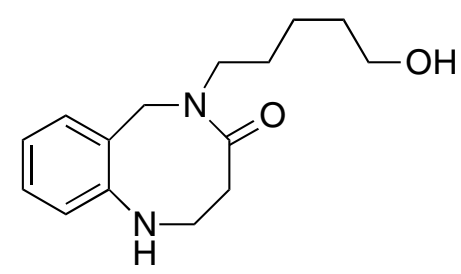

5-(5-Hydroxy-1-pentyl)-2,3,5,6-tetrahydro-1H-benzo[b][1,5]diazocin-4-one (Table 1, entry 4). A Schlenk tube was charged with CuI ( $9.6 \mathrm{mg}, 0.050 \mathrm{mmol}, 5.0 \mathrm{~mol} \%)$, 2-azetidinone (86 $\mathrm{mg}, 1.21 \mathrm{mmol}), \mathrm{K}_{2} \mathrm{CO}_{3}(280 \mathrm{mg}, 2.03 \mathrm{mmol})$, evacuated and backfilled with argon. $N, N^{\prime}-$ Dimethylethylenediamine $(11 \mu \mathrm{L}, 0.10 \mathrm{mmol}, 10 \mathrm{~mol} \%)$, 1-bromo-2-(5-hydroxy-1pentylaminomethyl)benzene $(195 \mu \mathrm{L}, 1.00 \mathrm{mmol})$, and toluene $(1.0 \mathrm{~mL})$ were added under argon. The Schlenk tube was sealed with a Teflon valve and the reaction mixture was stirred at $110{ }^{\circ} \mathrm{C}$ for $22 \mathrm{~h}$ in a preheated oil bath. The resulting light tan-green suspension was allowed to reach room temperature and then filtered through a silica gel plug $(0.5 \times 0.5 \mathrm{~cm})$ eluting with 10:1 $\mathrm{CH}_{2} \mathrm{Cl}_{2}-\mathrm{MeOH}(50 \mathrm{~mL})$. The filtrate was concentrated and the residue was purified by column chromatography on silica gel $\left(\mathrm{CH}_{2} \mathrm{Cl}_{2}-\mathrm{MeOH} 20: 1\right.$ followed by 10:1) to provide the desired product as white, fine crystals $\left(241 \mathrm{mg}, 92 \%\right.$ yield). Mp 102-103 ${ }^{\circ} \mathrm{C} .{ }^{1} \mathrm{H} \mathrm{NMR}(400 \mathrm{MHz}$, $\left.\mathrm{CDCl}_{3}\right): \delta 7.16-7.09(\mathrm{~m}, 2 \mathrm{H}), 6.87(\mathrm{td}, J=7.4,1.0 \mathrm{~Hz}, 1 \mathrm{H}), 6.72(\mathrm{~d}, J=7.8 \mathrm{~Hz}, 1 \mathrm{H}), 4.47(\mathrm{~s}$, 
2H), 3.98 (br s, 1H), 3.60 (q, $J=6.4 \mathrm{~Hz}, 2 \mathrm{H}), 3.41(\mathrm{br} \mathrm{m}, 2 \mathrm{H}), 3.30$ (t, $J=7.3 \mathrm{~Hz}, 2 \mathrm{H}), 2.95$ (t, $J$ $=6.4 \mathrm{~Hz}, 2 \mathrm{H}), 1.70(\mathrm{br} \mathrm{t}, J=5.2 \mathrm{~Hz}, 1 \mathrm{H}), 1.60-1.50(\mathrm{~m}, 4 \mathrm{H}), 1.40-1.30(\mathrm{~m}, 2 \mathrm{H}) .{ }^{13} \mathrm{C}$ NMR $(100$ $\left.\mathrm{MHz}, \mathrm{CDCl}_{3}\right): \delta 173.6,150.1,132.2,129.6,126.8,121.6,120.9,63.0,51.2,45.5,45.3,39.8$, 32.5, 27.3, 23.1. IR (neat, $\mathrm{cm}^{-1}$ ): 3336, 1622, 1488, 1437, 758. Anal. Calcd for $\mathrm{C}_{15} \mathrm{H}_{22} \mathrm{~N}_{2} \mathrm{O}_{2}: \mathrm{C}$, 68.67; H, 8.45. Found: C, 68.50; H, 8.47.

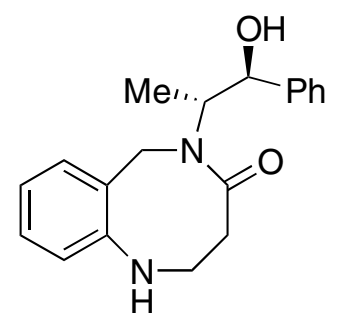

\section{5-[(1R,2S)-2-Hydroxy-1-methyl-2-phenylethyl]-2,3,5,6-tetrahydro-1H-benzo[b][1,5]-}

diazocin-4-one (Table 1, entry 5). A Schlenk tube was charged with CuI (9.6 mg, $0.050 \mathrm{mmol}$, $5.0 \mathrm{~mol} \%$ ), 2-azetidinone ( $86 \mathrm{mg}, 1.21 \mathrm{mmol}), \mathrm{K}_{2} \mathrm{CO}_{3}(280 \mathrm{mg}, 2.03 \mathrm{mmol}$ ), evacuated and backfilled with argon. A solution of $(1 S, 2 R)-N$-(2-bromobenzyl)norephedrine ${ }^{2}$ (325 mg, 1.01 $\mathrm{mmol})$ in PhMe $(1.0 \mathrm{~mL})$ was added under argon followed by $N, N^{\prime}$-dimethylethylenediamine (11 $\mu \mathrm{L}, 0.10 \mathrm{mmol}, 10 \mathrm{~mol} \%)$. The Schlenk tube was sealed with a Teflon valve and the reaction mixture was stirred at $110^{\circ} \mathrm{C}$ for $23 \mathrm{~h}$ in a preheated oil bath. The resulting tan suspension was allowed to reach room temperature, transferred to a solution of $30 \% \mathrm{aq} \mathrm{NH}_{3}(5 \mathrm{~mL})$ in water $(20$ $\mathrm{mL})$, and extracted with $\mathrm{CH}_{2} \mathrm{Cl}_{2}(4 \times 15 \mathrm{~mL})$. The combined organic layers were dried $\left(\mathrm{Na}_{2} \mathrm{SO}_{4}\right)$ and concentrated. The crude product mixture was dissolved in THF (10 mL) and, using a syringe, was transferred to a Schlenk tube filled with argon and capped with a rubber septum. Acetic acid $(115 \mu \mathrm{L}, 2.01 \mathrm{mmol})$ was added to the Schlenk tube, the rubber septum was replaced with a Teflon valve, and the sealed Schlenk tube was placed in an oil bath preheated to $110^{\circ} \mathrm{C}$. After stirring at $60{ }^{\circ} \mathrm{C}$ for $4 \mathrm{~h}$, the resulting pale yellow solution was allowed to reach room temperature, poured into $1 \mathrm{M}$ aq $\mathrm{Na}_{2} \mathrm{CO}_{3}(20 \mathrm{~mL})$, and extracted with $\mathrm{CH}_{2} \mathrm{Cl}_{2}(3 \times 20 \mathrm{~mL})$. The combined organic layers were dried $\left(\mathrm{Na}_{2} \mathrm{SO}_{4}\right)$, concentrated, and the residue was purified by column chromatography on silica gel $\left(\mathrm{CH}_{2} \mathrm{Cl}_{2}-\mathrm{MeOH} 30: 1\right)$. The product was dissolved in $\mathrm{CH}_{2} \mathrm{Cl}_{2}(10 \mathrm{~mL})$ and concentrated to $\sim 2 \mathrm{~mL}$ followed by addition of hexane $(\sim 15 \mathrm{~mL})$. The resulting crystals were collected and dried to give the desired product ( $215 \mathrm{mg}, 69 \%$ yield) as fine, white needles. Mp 213-215 ${ }^{\circ} \mathrm{C} .{ }^{1} \mathrm{H}$ NMR $\left(400 \mathrm{MHz}, \mathrm{CDCl}_{3}\right): \delta$ 7.27-7.14 (m, 4H), 7.10-

\footnotetext{
${ }^{2}$ Leung, W.; Cosway, S.; Jones, R. H. V.; McCann, H.; Wills, M. J. Chem. Soc., Perkin Trans. 1 2001, 2588.
} 
7.05 (m, 3H), 6.87 (td, J = 7.8, 1.4 Hz), $6.71(\mathrm{dd}, \mathrm{J}=7.8,1.4 \mathrm{~Hz}), 5.82(\mathrm{~s}, 1 \mathrm{H}), 4.79$ (s, 1H), 4.66 $(\mathrm{d}, \mathrm{J}=16.0 \mathrm{~Hz}, 1 \mathrm{H}), 4.32(\mathrm{~d}, \mathrm{~J}=16.0 \mathrm{~Hz}, 1 \mathrm{H}), 4.13(\mathrm{br} \mathrm{t}, \mathrm{J}=5.3 \mathrm{~Hz}, 1 \mathrm{H}), 3.60-3.45(\mathrm{~m}, 2 \mathrm{H})$, 3.34-3.27 (m, 1H), 3.10-2.93 (m, 2H), $1.12(\mathrm{~d}, \mathrm{~J}=7.0 \mathrm{~Hz}, 3 \mathrm{H}) .{ }^{13} \mathrm{C}$ NMR $\left(100 \mathrm{MHz}, \mathrm{CDCl}_{3}\right): \delta$ 175.0, 149.4, 142.9, 131.5, 129.2, 128.0, 126.9, 125.9, 123.0, 120.3, 118.9, 76.4, 65.9, 54.7, 44.2, 39.5, 9.6. IR (neat, $\mathrm{cm}^{-1}$ ): 3355, 3215, 1618, 1604, 1489, 1472, 1037, 767, 704. Anal. Calcd for $\mathrm{C}_{19} \mathrm{H}_{22} \mathrm{~N}_{2} \mathrm{O}_{2}$ : C, 73.52; H, 7.14. Found: C, 73.22; H, 7.13.

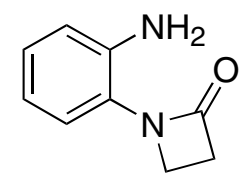

$N$-(2-Aminophenyl)-2-azetidinone. A Schlenk tube was charged with CuI (48 mg, $0.25 \mathrm{mmol}$, $5.0 \mathrm{~mol} \%$ ), 2-bromoaniline ( $861 \mathrm{mg}, 5.00 \mathrm{mmol}$ ), 2-azetidinone (430 mg, $6.05 \mathrm{mmol}$ ), $\mathrm{K}_{2} \mathrm{CO}_{3}$ (1.40 mg, $10.1 \mathrm{mmol}$ ), evacuated and backfilled with argon. $N, N^{\prime}$-Dimethylethylenediamine (54 $\mu \mathrm{L}, 0.507 \mathrm{mmol}, 10 \mathrm{~mol} \%)$ and toluene $(5.0 \mathrm{~mL})$ were added under argon. The Schlenk tube was sealed with a Teflon valve and the reaction mixture was stirred at $110{ }^{\circ} \mathrm{C}$ for $22 \mathrm{~h}$ in a preheated oil bath. The resulting black suspension was allowed to reach room temperature and filtered through a silica gel plug $(0.5 \times 1 \mathrm{~cm})$ eluting with ethyl acetate $(100 \mathrm{~mL})$. The filtrate was concentrated and the residue was purified by column chromatography on silica gel (hexane-ethyl acetate 1:4, followed by ethyl acetate, followed by ethyl acetate-MeOH 10:1). Fractions 14-23 provided $N$-(2-aminophenyl)-2-azetidinone (582 $\mathrm{mg}, 72 \%$ yield) as a purple-brown solid. Mp 62-64 ${ }^{\circ} \mathrm{C} .{ }^{1} \mathrm{H}$ NMR $\left(400 \mathrm{MHz}, \mathrm{CDCl}_{3}\right): \delta 6.99(\operatorname{td}, J=7.8,1.5 \mathrm{~Hz}, 1 \mathrm{H}), 6.84(\mathrm{dd}, J=7.8,1.5$ $\mathrm{Hz}, 1 \mathrm{H}), 6.74-6.67(\mathrm{~m}, 2 \mathrm{H}), 4.76(\mathrm{br} \mathrm{s}, 2 \mathrm{H}), 3.67(\mathrm{t}, J=4.4 \mathrm{~Hz}, 2 \mathrm{H}), 3.04(\mathrm{t}, J=4.4 \mathrm{~Hz}, 2 \mathrm{H})$. ${ }^{13} \mathrm{C}$ NMR $\left(100 \mathrm{MHz}, \mathrm{CDCl}_{3}\right): \delta 164.8,139.7,126.9,126.0,119.5,118.4,118.0,39.3,34.3$. IR (neat, $\mathrm{cm}^{-1}$ ): $3409,3315,3227,1718,1636,1505,1462,1379,1315,1143,747$. Anal. Calcd for $\mathrm{C}_{9} \mathrm{H}_{10} \mathrm{~N}_{2} \mathrm{O}$ : C, 66.65; H, 6.21. Found: C, 66.81; H, 6.29. Fractions $35-37$ provided 1,3,4,5tetrahydrobenzo[b][1,4]diazepin-2-one (32 $\mathrm{mg}$ of $\sim 90 \%$ pure material, $\sim 3 \%$ yield).<smiles>O=C1CCNc2ccccc2N1</smiles>

1,3,4,5-Tetrahydrobenzo $[b][1,4]$ diazepin-2-one (Table 1, entry 6). A Schlenk tube was charged with $\mathrm{CuI}$ (9.6 mg, $0.050 \mathrm{mmol}, 5.0 \mathrm{~mol} \%)$, 2-iodoaniline (220 mg, $1.00 \mathrm{mmol}), 2$ - 
azetidinone ( $86 \mathrm{mg}, 1.21 \mathrm{mmol}$ ), $\mathrm{K}_{3} \mathrm{PO}_{4}(430 \mathrm{mg}, 2.03 \mathrm{mmol}$ ), evacuated and backfilled with argon. $N, N^{\prime}$-Dimethylethylenediamine $(11 \mu \mathrm{L}, 0.10 \mathrm{mmol}, 10 \mathrm{~mol} \%)$ and toluene $(1.0 \mathrm{~mL})$ were added under argon. The Schlenk tube was sealed with a Teflon valve and the reaction mixture was stirred at $100{ }^{\circ} \mathrm{C}$ for $5 \mathrm{~h}$ in a preheated oil bath. The resulting thick, brown suspension was allowed to reach room temperature and dodecane $\left(46 \mu \mathrm{L}\right.$, internal GC standard) and $\mathrm{CH}_{2} \mathrm{Cl}_{2}(3$ $\mathrm{mL}$ ) were added. GC analysis of the crude reaction mixture revealed $>99 \%$ conversion of 2 iodoaniline with ca. $95 \%$ formation of $N$-(2-aminophenyl)-2-azetidinone and $<5 \%$ of $1,3,4,5$ tetrahydrobenzo $[b][1,4]$-diazepin-2-one. The reaction mixture was filtered through a silica gel plug $(0.5 \times 0.5 \mathrm{~cm})$ eluting with $10: 1 \mathrm{CH}_{2} \mathrm{Cl}_{2}-\mathrm{MeOH}(50 \mathrm{~mL})$ and the filtrate was concentrated. The semi-solid residue in the evaporation flask (ca. $270 \mathrm{mg}$ ) was transferred to a Schlenk tube, which was then evacuated, backfilled with argon, and sealed with a rubber septum. The evaporation flask was rinsed with warm toluene $(2+2 \times 1.5 \mathrm{~mL})$ under argon and the washings were transferred to the Schlenk tube using a syringe. $\operatorname{Ti}(\mathrm{OiPr})_{4}(148 \mu \mathrm{L}, 0.501 \mathrm{mmol})$ was added to Schlenk tube under argon, the septum on the Schlenk tube was replaced with a Teflon valve under a stream of argon, and the sealed Schlenk tube was placed in an oil bath preheated to $110{ }^{\circ} \mathrm{C}$. After stirring at $110{ }^{\circ} \mathrm{C}$ for $24 \mathrm{~h}$, the reaction mixture was allowed to reach room temperature and then filtered through a silica gel plug $(0.5 \times 0.5 \mathrm{~cm})$ eluting with $10: 1 \mathrm{CH}_{2} \mathrm{Cl}_{2^{-}}$ $\mathrm{MeOH}(50 \mathrm{~mL})$. The filtrate was concentrated and the residue was purified by column chromatography on silica gel $\left(\mathrm{CH}_{2} \mathrm{Cl}_{2}-\mathrm{MeOH} 20: 1\right)$ to provide the desired product as a tan solid (154 mg, 95\% yield). Mp 140-142 ${ }^{\circ} \mathrm{C} .{ }^{1} \mathrm{H}$ NMR (400 MHz, $\mathrm{CDCl}_{3}$ ): $\delta 8.33$ (br s, 1H), 6.96 (td, $J=7.8,1.5 \mathrm{~Hz}, 1 \mathrm{H}), 6.90(\mathrm{dd}, J=7.8,1.5 \mathrm{~Hz}, 1 \mathrm{H}), 6.82(\mathrm{td}, J=7.8,1.5 \mathrm{~Hz}, 1 \mathrm{H}), 6.73(\mathrm{dd}, J=$ 7.8, $1.5 \mathrm{~Hz}, 1 \mathrm{H}), 3.87(\mathrm{br} \mathrm{s}, 1 \mathrm{H}), 3.67$ (t, $J=5.7 \mathrm{~Hz}, 2 \mathrm{H}), 2.73$ (t, $J=5.7 \mathrm{~Hz}, 2 \mathrm{H}) .{ }^{13} \mathrm{C} \mathrm{NMR}$ $\left(100 \mathrm{MHz}, \mathrm{CDCl}_{3}\right): \delta 174.0,138.7,126.2,125.3,122.1,120.5,119.8,45.5,36.1$. IR (neat, $\mathrm{cm}^{-}$ $\left.{ }^{1}\right): 3405,3355,1662,1505,1431,1418,748$. Anal. Calcd for $\mathrm{C}_{9} \mathrm{H}_{10} \mathrm{~N}_{2} \mathrm{O}: \mathrm{C}, 66.65 ; \mathrm{H}, 6.21$. Found: C, 66.29; H, 6.22.

If the copper-catalyzed coupling step was performed without the $N, N^{\prime}$-dimethylethylenediamine ligand, only $7 \%$ conversion of 2-iodoaniline was observed by $\mathrm{GC}$ analysis after $5 \mathrm{~h}$ at $100{ }^{\circ} \mathrm{C}$. 


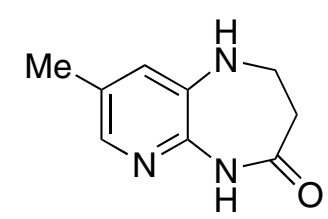

8-Methyl-1,2,3,5-tetrahydropyrido[3,4-b][1,4]diazepin-4-one (Table 1, entry 7). A Schlenk tube was charged with $\mathrm{CuI}(9.6 \mathrm{mg}, 0.050 \mathrm{mmol}, 5.0 \mathrm{~mol} \%)$, 2-amino-3-bromo-5methylpyridine (188 mg, $1.01 \mathrm{mmol})$, 2-azetidinone (86 mg, $1.21 \mathrm{mmol}), \mathrm{K}_{2} \mathrm{CO}_{3}(280 \mathrm{mg}, 2.03$ mmol), evacuated and backfilled with argon. $N, N^{\prime}$-Dimethylethylenediamine $(11 \mu \mathrm{L}, 0.10$ mmol, $10 \mathrm{~mol} \%)$ and toluene $(1.0 \mathrm{~mL})$ were added under argon. The Schlenk tube was sealed with a Teflon valve and the reaction mixture was stirred at $110{ }^{\circ} \mathrm{C}$ for $23 \mathrm{~h}$ in a preheated oil bath. The resulting brown-black suspension was allowed to reach room temperature, filtered through a silica gel plug $(0.5 \times 0.5 \mathrm{~cm})$ eluting with $10: 1 \mathrm{CH}_{2} \mathrm{Cl}_{2}-\mathrm{MeOH}(50 \mathrm{~mL})$, and the red filtrate was concentrated. The semi-solid residue in the evaporation flask (ca. $155 \mathrm{mg}$ ) was transferred to a Schlenk tube, which was then evacuated, backfilled with argon, and sealed with a rubber septum. The evaporation flask was rinsed with warm toluene $(2+2 \times 1.5 \mathrm{~mL})$ under argon and the washings were transferred to the Schlenk tube using a syringe. $\operatorname{Ti}(\mathrm{OiPr})_{4}(148 \mu \mathrm{L}, 0.501$ mmol) was added to Schlenk tube under argon, the septum on the Schlenk tube was replaced with a Teflon valve under a stream of argon, and the sealed Schlenk tube was placed in an oil bath preheated to $110^{\circ} \mathrm{C}$. After stirring at $110^{\circ} \mathrm{C}$ for $24 \mathrm{~h}$, the reaction mixture was allowed to reach room temperature and then filtered through a silica gel plug $(0.5 \times 0.5 \mathrm{~cm})$ eluting with 10:1 $\mathrm{CH}_{2} \mathrm{Cl}_{2}-\mathrm{MeOH}(50 \mathrm{~mL})$. The filtrate was concentrated and the residue was purified by column chromatography on silica gel $\left(\mathrm{CH}_{2} \mathrm{Cl}_{2}-\mathrm{MeOH} 20: 1\right)$ to provide the desired product as a pink solid (106 mg, 59\% yield). Mp 192-194 ${ }^{\circ} \mathrm{C} .{ }^{1} \mathrm{H} \mathrm{NMR} \mathrm{(400} \mathrm{MHz,} \mathrm{CDCl}_{3}$ ): $\delta 8.52$ (br s, 1H), 7.72 (s, $1 \mathrm{H}), 6.80(\mathrm{~s}, 1 \mathrm{H}), 3.95$ (br s, 1H), 3.58-3.49 (m, 2H), 2.86-2.80 (m, 2H), $2.22(\mathrm{~s}, 3 \mathrm{H}) .{ }^{13} \mathrm{C} \mathrm{NMR}$ $\left(100 \mathrm{MHz}, \mathrm{CDCl}_{3}\right): \delta 172.4,139.0,136.6,133.3,129.5,126.6,41.9,38.3,17.4$. IR (neat, $\left.\mathrm{cm}^{-1}\right)$ : $3354,3324,1653,1605,1533,1491,1394,1283$, 855. Anal. Calcd for $\mathrm{C}_{9} \mathrm{H}_{11} \mathrm{~N}_{3} \mathrm{O}$ : C, 61.00; $\mathrm{H}$, 6.26. Found: C, 60.72; H, 6.24.

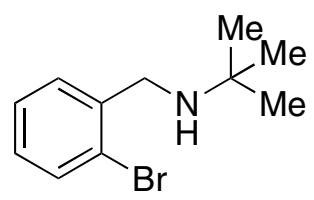

(2-Bromo-benzyl)-tert-butylamine. A $100 \mathrm{~mL}$ round bottom flask was charged with 2bromobenzaldehyde $(2.9 \mathrm{~mL}, 25 \mathrm{mmol}), t$-butylamine $(3.94 \mathrm{~mL}, 37.5 \mathrm{mmol})$, toluene $(20 \mathrm{~mL})$ 
and activated $4 \AA$ MS and was allowed to stir overnight under an argon atmosphere. The mixture was filtered through celite and concentrated by rotary evaporation. The residual oil was dissolved in $\mathrm{MeOH}(30 \mathrm{~mL})$, the solution was cooled to $0{ }^{\circ} \mathrm{C}$ (water-ice bath), and solid $\mathrm{NaBH}_{4}$ (2.90 $\mathrm{mg}, 76.7 \mathrm{mmol}$ ) was added in several portions over $15 \mathrm{~min}$ (caution: hydrogen gas evolution). The resulting white suspension was stirred at $0{ }^{\circ} \mathrm{C}$ for $15 \mathrm{~min}$, then the cooling bath was removed and the suspension was stirred at room temperature for $18 \mathrm{~h}$. The reaction was poured into $1 \mathrm{M} \mathrm{HCl}(40 \mathrm{~mL})$ and extracted with ether. The aqueous layer was basified with a solution of $\mathrm{NaOH}(4.0 \mathrm{~g})$ in water $(50 \mathrm{~mL})$ and extracted with ether $(3 \times 100 \mathrm{~mL})$. The organic layer was dried $\left(\mathrm{Na}_{2} \mathrm{SO}_{4}\right)$ and concentrated by rotary evaporation to provide the desired product as a colorless liquid (4.82 g, 80\% yield). $\left.{ }^{1} \mathrm{H} \mathrm{NMR} \mathrm{(400} \mathrm{MHz,} \mathrm{CDCl}_{3}\right): \delta 7.51$ (dd, $J=7.6,1.4$ $\mathrm{Hz}, 1 \mathrm{H}), 7.45$ (dd, $J=7.6,1.4 \mathrm{~Hz}, 1 \mathrm{H}), 7.26(\mathrm{td}, J=7.6,1.4 \mathrm{~Hz}, 1 \mathrm{H}), 7.10$ (td, $J=7.6,1.4 \mathrm{~Hz}$ $1 \mathrm{H}), 3.80$ (s, 2H), 1.19 (s, 9H), 1.13 (br-s, 1H). ${ }^{13} \mathrm{C}$ NMR (100 MHz, $\left.\mathrm{CDCl}_{3}\right): \delta 140.5,132.8$, $130.7,128.6,127.8,124.1,51.0,47.5,29.3$. IR (neat, $\mathrm{cm}^{-1}$ ): 1567, 1470, 1440, 1362, 1217 , 1024, 748. Anal. Calcd for $\mathrm{C}_{11} \mathrm{H}_{16} \mathrm{BrN}$ : C, 54.56; H, 6.66. Found: C, 54.42 ; H, 6.75.

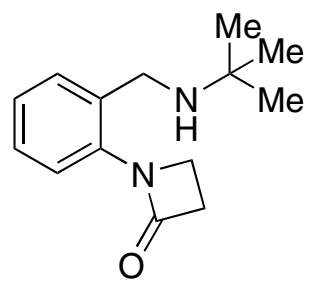

1-[2-(tert-Butylaminomethylphenyl]-2-azetidinone. A $50 \mathrm{~mL}$ Schlenk tube was charged with CuI (96 mg, $0.50 \mathrm{mmol}, 5.0 \mathrm{~mol} \%$ ), 2-azetidinone (860 mg, $12.1 \mathrm{mmol}), \mathrm{K}_{2} \mathrm{CO}_{3}(2.80 \mathrm{~g}, 20.3$ mmol), evacuated and backfilled with argon. $N, N^{\prime}$-Dimethylethylenediamine $(108 \mu \mathrm{L}, 0.101$ mmol, $10 \mathrm{~mol} \%)$, (2-bromobenzyl)-tert-butylamine (2.42 g, $10.0 \mathrm{mmol})$, and toluene (10.0 $\mathrm{mL})$ were added under argon. The Schlenk tube was sealed with a Teflon valve and the reaction mixture was stirred at $110{ }^{\circ} \mathrm{C}$ for $23 \mathrm{~h}$ in a preheated oil bath. The resulting blue-gray suspension was allowed to reach room temperature, poured into a solution of $30 \% \mathrm{aq} \mathrm{NH}_{3}(10$ $\mathrm{mL})$ in water $(50 \mathrm{~mL})$, and extracted with $\mathrm{CH}_{2} \mathrm{Cl}_{2}(4 \times 50 \mathrm{~mL})$. The combined organic layers were dried $\left(\mathrm{Na}_{2} \mathrm{SO}_{4}\right)$ and concentrated by rotary evaporation and the residue was purified by column chromatography on silica gel $\left(\mathrm{CH}_{2} \mathrm{Cl}_{2}-\mathrm{MeOH}\right.$ 10:1 then $\mathrm{CH}_{2} \mathrm{Cl}_{2}-\mathrm{MeOH}-\mathrm{TEA}$ 10:1:0.5) to provide the desired product as a colorless oil $\left(2.1 \mathrm{~g}, 90 \%\right.$ yield). ${ }^{1} \mathrm{H}$ NMR $\left(400 \mathrm{MHz}, \mathrm{CDCl}_{3}\right): \delta$ $7.39(\mathrm{dd}, \mathrm{J}=7.7,1.6 \mathrm{~Hz}, 1 \mathrm{H}), 7.31(\mathrm{dd}, \mathrm{J}=7.8,1.6 \mathrm{~Hz}, 1 \mathrm{H}), 7.18(\mathrm{td}, \mathrm{J}=7.7,1.6 \mathrm{~Hz}, 1 \mathrm{H}), 7.15$ $(\mathrm{td}, \mathrm{J}=7.7,1.6 \mathrm{~Hz}, 1 \mathrm{H}), 3.71(\mathrm{~s}, 2 \mathrm{H}), 7.70(\mathrm{t}, \mathrm{J}=4.5 \mathrm{~Hz}, 2 \mathrm{H}), 2.99$ (t, J = 4.4 Hz, 2H), 1.26 (br- 
s, $1 \mathrm{H}), 1.14(\mathrm{~s}, 9 \mathrm{H}) .{ }^{13} \mathrm{C}$ NMR $\left(100 \mathrm{MHz}, \mathrm{CDCl}_{3}\right): \delta 165.4,135.7,134.4,130.5,127.1,125.9$, 122.4, 50.3, 43.6, 41.3, 35.8, 28.7. IR (neat, $\mathrm{cm}^{-1}$ ): 3308, 1748, 1601, 1580, 1494, 1454, 1361, 1230, 1152, 753. HRMS-EI calcd for $\mathrm{C}_{14} \mathrm{H}_{20} \mathrm{NO}\left(\mathrm{M}+\mathrm{H}^{+}\right)$, 233.1654; found, 233.1642 .

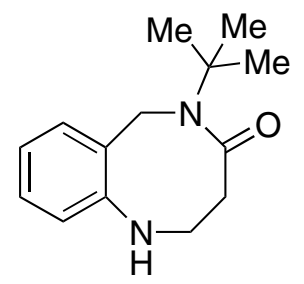

5-tert-Butyl-2,3,5,6-tetrahydro-1H-benzo $[\boldsymbol{b}][1,5]$ diazocin-4-one. From the previous experiment, 5-tert-Butyl-2,3,5,6-tetrahydro- $1 H$-benzo[ $b][1,5]$ diazocin-4-one was isolated as a white solid (183 mg, 8\% yield). Mp 195-198 ${ }^{\circ} \mathrm{C} .{ }^{1} \mathrm{H}$ NMR (400 MHz, $\left.\mathrm{CDCl}_{3}\right): \delta 7.05-7.09(\mathrm{~m}$, 2H), 6.79 (td, J = 7.4, $0.9 \mathrm{~Hz}, 1 \mathrm{H}), 6.62(\mathrm{~d}, \mathrm{~J}=7.9 \mathrm{~Hz}, 1 \mathrm{H}), 4.68(\mathrm{~s}, 2 \mathrm{H}), 4.05$ (br-s, 1H), 3.51 (m, 2H), $3.02(\mathrm{~m}, 2 \mathrm{H}), 1.32(\mathrm{~s}, 9 \mathrm{H}){ }^{13} \mathrm{C} \mathrm{NMR}\left(100 \mathrm{MHz}, \mathrm{CDCl}_{3}\right): \delta 173.9,150.4,131.7,128.2$, 124.3, 119.5, 118.6, 57.7, 49.1, 44.6, 41.1, 28.6. IR (neat, $\mathrm{cm}^{-1}$ ): 3426, 1630, 1473, 1415, 1357, 1342, 756. Anal. Calcd for $\mathrm{C}_{14} \mathrm{H}_{20} \mathrm{~N}_{2} \mathrm{O}: \mathrm{C}, 72.38 ; \mathrm{H}, 8.68$. Found: C, 72.38; H, 8.75.

\section{Effect of various transamidation catalysts on the ring expansion reaction (Table 2)}
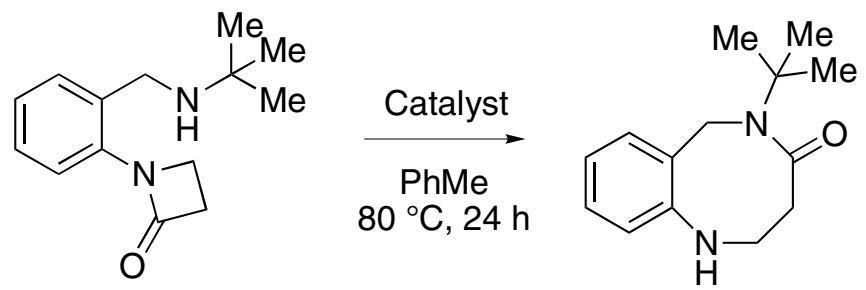

Two of eight Schlenk tubes were charged with the following amounts of $\operatorname{Sc}(\mathrm{OTf})_{3}$ (Aldrich): $12.3 \mathrm{mg}(0.025 \mathrm{mmol}, 5 \mathrm{~mol} \%)$ and $123 \mathrm{mg}(0.25 \mathrm{mmol}, 50 \mathrm{~mol} \%)$. All eight Schlenk tubes were evacuated and backfilled with argon. A solution of 1-[2-(tert-Butylaminomethylphenyl]-2azetidinone $(116 \mathrm{mg}, 0.500 \mathrm{mmol})$ and dodecane $(225 \mu \mathrm{L}$, internal GC standard) in toluene $(2.5$ $\mathrm{mL}$ ) was added to each Schlenk tube under argon followed by the following catalysts in five of the Schlenk tubes: acetic acid: $1.4 \mu \mathrm{L}(0.025 \mathrm{mmol}, 5 \mathrm{~mol} \%)$ and $14 \mu \mathrm{L}(0.25 \mathrm{mmol}, 50 \mathrm{~mol} \%)$; acetic acid/triethylamine: $1.4 \mu \mathrm{L}$ acetic acid $(0.025 \mathrm{mmol}, 5 \mathrm{~mol} \%) / 7.0 \mu \mathrm{L}$ triethylamine $(0.050$ mmol, $10 \mathrm{~mol} \%)$; and $\mathrm{Ti}\left(\mathrm{NMe}_{2}\right)_{4} ; 5.8 \mu \mathrm{L}(0.025 \mathrm{mmol}, 5 \mathrm{~mol} \%)$ and $58 \mu \mathrm{L}(0.25 \mathrm{mmol}, 50$ mol\%). The Schlenk tubes were sealed with Teflon valves and the reaction mixtures were stirred 
in a preheated oil bath at $80{ }^{\circ} \mathrm{C}$ and monitored by $\mathrm{GC}$ analysis. Ethyl acetate $(3 \mathrm{~mL})$ and $1 \mathrm{M}$ aq $\mathrm{Na}_{2} \mathrm{CO}_{3}(2 \mathrm{~mL})$ were added to each Schlenk tube and the organic layer was analyzed by GC. The results are presented in Table 2. The combined organic layers (Table 2, Entry 6) were dried $\left(\mathrm{Na}_{2} \mathrm{SO}_{4}\right)$ and concentrated by rotary evaporation and the residue was purified by column chromatography on silica gel $\left(\mathrm{CH}_{2} \mathrm{Cl}_{2}-\mathrm{MeOH} 10: 1\right)$ to provide the desired product as a white solid (110 mg, 95\% yield). Mp 195-196 ${ }^{\circ} \mathrm{C} .{ }^{1} \mathrm{H}$ NMR (400 MHz, $\left.\mathrm{CDCl}_{3}\right): \delta$ 7.05-7.10 (m, 2H), $6.78(\mathrm{td}, \mathrm{J}=7.4,1.0 \mathrm{~Hz}, 1 \mathrm{H}), 6.63(\mathrm{~d}, \mathrm{~J}=7.9 \mathrm{~Hz}, 1 \mathrm{H}), 4.69$ (s, 2H), 4.23 (br-s, 1H), 3.52 (m, 2H), $3.08(\mathrm{~m}, 2 \mathrm{H}), 1.38(\mathrm{~s}, 9 \mathrm{H})$

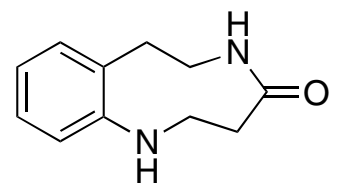

1,2,3,5,6,7-hexahydrobenzo[f][1,5]diazonin-4-one (Table 3, entry 1). A Schlenk tube was charged with $\mathrm{CuI}(9.6 \mathrm{mg}, 0.050 \mathrm{mmol}, 5.0 \mathrm{~mol} \%)$, 2-azetidinone (86 mg, $1.21 \mathrm{mmol}), \mathrm{K}_{2} \mathrm{CO}_{3}$ (280 mg, $2.03 \mathrm{mmol}$ ), evacuated and backfilled with argon. 2-(2-Bromophenyl)ethylamine (142 $\mu \mathrm{L}, 1.00 \mathrm{mmol})$ and toluene $(1.0 \mathrm{~mL})$ were added under argon. The Schlenk tube was sealed with a Teflon valve and the reaction mixture was stirred at $110{ }^{\circ} \mathrm{C}$ for $22 \mathrm{~h}$ in a preheated oil bath. The resulting black suspension was allowed to reach room temperature and then dodecane (46 $\mu \mathrm{L}$, internal GC standard) and 10:1 $\mathrm{CH}_{2} \mathrm{Cl}_{2}-\mathrm{MeOH}(10 \mathrm{~mL})$ were added. GC analysis of the supernatant solution indicated $>99 \%$ conversion of the aryl bromide starting material and $19 \%$ yield of the indoline sideproduct. The reaction mixture was filtered through a silica gel plug $(0.5 \times 0.5 \mathrm{~cm})$ eluting with $10: 1 \mathrm{CH}_{2} \mathrm{Cl}_{2}-\mathrm{MeOH}(50 \mathrm{~mL})$, the filtrate was concentrated, and the residue was purified by column chromatography on silica gel $\left(\mathrm{CH}_{2} \mathrm{Cl}_{2}-\mathrm{MeOH} 15: 1\right)$ to afford the desired product (130 mg, 68\% yield) as a pale gray solid. Mp $184-186{ }^{\circ} \mathrm{C}$. The ${ }^{1} \mathrm{H}$ and ${ }^{13} \mathrm{C} \mathrm{NMR}$ spectra displayed two sets of signals due to rotamers of the cyclic amide with the $Z: E$ ratio of $2: 3$. In addition, the $Z$-rotamer is chiral causing the protons in all methylene groups to become chemically nonequivalent. ${ }^{1} \mathrm{H}$ NMR $\left(400 \mathrm{MHz} \mathrm{CDCl}_{3}\right): \delta$ 7.26-7.17 (m, 1H), 7.10 (d, J = 7.8 $\mathrm{Hz}, 0.6 \mathrm{H}), 7.06-7.01(\mathrm{~m}, 1.4 \mathrm{H}), 6.96(\mathrm{td}, \mathrm{J}=7.8,1.4 \mathrm{~Hz}, 0.6 \mathrm{H}), 6.90-6.80(\mathrm{~m}, 1 \mathrm{H}), 5.04$ (br s, 0.4H), 4.16-4.07 (m, 0.4H), 3.87-3.75 (m, 0.4H), 3.67-3.57 (m, 1.6H), 3.52-3.38 (m, 1.6H), 3.28$3.17(\mathrm{~m}, 0.4 \mathrm{H}), 3.07$ (br s, 0.6H), 2.95-2.87 (m, 1.2H), 2.67-2.57 (m, 0.4H), 2.48-2.24 (m, 2.4H). ${ }^{13} \mathrm{C}$ NMR $\left(100 \mathrm{MHz}, \mathrm{CDCl}_{3}\right): \delta 176.5,176.3,148.7,146.8,133.4,130.6,130.5,128.4,128.1$, 123.6, 123.2, 121.3, 119.2, 51.3, 45.6, 44.4, 41.8, 38.1, 36.7, 33.1, 29.8. IR (neat, $\mathrm{cm}^{-1}$ ): 3327 , 
1653, 1498, 1473, 1247, 758. Anal. Calcd for $\mathrm{C}_{11} \mathrm{H}_{14} \mathrm{~N}_{2} \mathrm{O}: \mathrm{C}, 69.45 ; \mathrm{H}, 7.42$. Found: C, 69.54; $\mathrm{H}$, 7.52 .

If the reaction was performed with the $N, N^{\prime}$-dimethylethylenediamine ligand $(11 \mu \mathrm{L}, 0.10 \mathrm{mmol}$, $10 \mathrm{~mol} \%$ ), GC analysis of the reaction mixture indicated $>99 \%$ conversion of the aryl bromide starting material, $37 \%$ yield of the indoline sideproduct, and only $48 \%$ yield (GC) of the desired 1,2,3,5,6,7-hexahydrobenzo[f][1,5]diazonin-4-one.

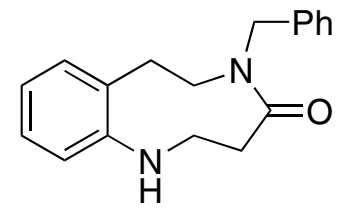

5-Benzyl-1,2,3,5,6,7-hexahydrobenzo[f][1,5]diazonin-4-one (Table 3, entry 2). A Schlenk tube was charged with CuI (9.6 mg, $0.050 \mathrm{mmol}, 5.0 \mathrm{~mol} \%)$, 2-azetidinone (86 mg, $1.21 \mathrm{mmol}$ ), $\mathrm{K}_{2} \mathrm{CO}_{3}(280 \mathrm{mg}, 2.03 \mathrm{mmol})$, evacuated and backfilled with argon. $N$-Benzyl-2-(2bromophenyl)ethylamine $^{3}(227 \mu \mathrm{L}, 1.00 \mathrm{mmol}) N, N^{\prime}$-dimethylethylenediamine $(11 \mu \mathrm{L}, 0.10$ mmol, $10 \mathrm{~mol} \%)$, and toluene $(1.0 \mathrm{~mL})$ were added under argon. The Schlenk tube was sealed with a Teflon valve and the reaction mixture was stirred at $110{ }^{\circ} \mathrm{C}$ for $24 \mathrm{~h}$ in a preheated oil bath. The resulting black suspension was allowed to reach room temperature and then dodecane (46 $\mu \mathrm{L}$, internal $\mathrm{GC}$ standard) and $\mathrm{CH}_{2} \mathrm{Cl}_{2}$ were added. $\mathrm{GC}$ analysis of the reaction mixture indicated $>98 \%$ conversion of the aryl bromide and $\sim 17 \%$ yield of $N$-benzylindoline. The reaction mixture was transferred to a solution of $30 \%$ aq $\mathrm{NH}_{3}(5 \mathrm{~mL})$ in water $(20 \mathrm{~mL})$, and extracted with $\mathrm{CH}_{2} \mathrm{Cl}_{2}(3 \times 20 \mathrm{~mL})$. The combined organic layers were dried $\left(\mathrm{Na}_{2} \mathrm{SO}_{4}\right)$, concentrated, and the residue was purified by column chromatography on silica gel (ethyl acetate-MeOH 15:1). The product was dissolved in $\mathrm{CH}_{2} \mathrm{Cl}_{2}(20 \mathrm{~mL})$, the solution was concentrated by rotary evaporation, and the residual oil was suspended in hexane $(20 \mathrm{~mL})$. Seed crystals of the desired product $(<1 \mathrm{mg})$ were added to the mixture causing slow crystallization. The supernatant solution was decanted and the crystalline residue in the flask was dried under vacuum to afford pure desired product (218 mg, 78\% yield) as white, fine crystals. Mp 101-102 ${ }^{\circ} \mathrm{C} .{ }^{1} \mathrm{H}$ NMR $\left(400 \mathrm{MHz}, \mathrm{CDCl}_{3}\right): \delta$ 7.37-7.19 (m, 6H), $7.10(\mathrm{dd}, \mathrm{J}=7.8,1.4 \mathrm{~Hz}, 1 \mathrm{H}), 6.99(\mathrm{dd}, \mathrm{J}$ $=7.8,1.4 \mathrm{~Hz}, 1 \mathrm{H}), 6.94(\mathrm{td}, \mathrm{J}=7.8,1.4 \mathrm{~Hz}, 1 \mathrm{H}), 4.62(\mathrm{br} \mathrm{s}, 2 \mathrm{H}), 3.65(\mathrm{t}, \mathrm{J}=5.3 \mathrm{~Hz}, 2 \mathrm{H}), 3.61-$

\footnotetext{
${ }^{3}$ Mori, M.; Chiba, K.; Ban, Y. J. Org. Chem. 1978, 43, 1684.
} 
$3.56(\mathrm{~m}, 2 \mathrm{H}), 2.87(\mathrm{~s}, 1 \mathrm{H}), 2.84-2.79(\mathrm{~m}, 2 \mathrm{H}), 2.49(\mathrm{br} \mathrm{s}, 2 \mathrm{H}) .{ }^{13} \mathrm{C} \mathrm{NMR}\left(100 \mathrm{MHz}, \mathrm{CDCl}_{3}\right): \delta$ 173.3, 147.1, 137.3, 133.1, 130.6, 128.8, 128.5, 128.4, 127.6, 124.0, 123.2, 51.5, 49.5, 48.2, 34.2, 33.6. IR (neat, $\mathrm{cm}^{-1}$ ): $3362,1624,1497,1472,1453,1251,1170,752$. Anal. Calcd for $\mathrm{C}_{18} \mathrm{H}_{20} \mathrm{~N}_{2} \mathrm{O}: \mathrm{C}, 77.11 ; \mathrm{H}, 7.19$. Found: $\mathrm{C}, 77.25 ; \mathrm{H}, 7.14$.

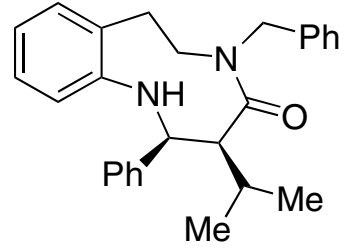

cis-5-Benzyl-3-isopropyl-2-phenyl-1,2,3,5,6,7-hexahydrobenzo[f][1,5]diazonin-4-one (Table 3, entry 3). A Schlenk tube was charged with CuI (9.6 mg, $0.050 \mathrm{mmol}, 5.0 \mathrm{~mol} \%)$, (rac)-cis-3isopropyl-4-phenyl-2-azetidinone ${ }^{4}(226 \mathrm{mg}, 1.20 \mathrm{mmol}), \mathrm{K}_{2} \mathrm{CO}_{3}(280 \mathrm{mg}, 2.03 \mathrm{mmol})$, evacuated and backfilled with argon. $N$-Benzyl-2-(2-bromophenyl)ethylamine ${ }^{5}(227 \mu \mathrm{L}, 1.00 \mathrm{mmol}), N, N^{\prime}-$ dimethylethylenediamine ( $11 \mu \mathrm{L}, 0.10 \mathrm{mmol}, 10 \mathrm{~mol} \%)$ and toluene $(1.0 \mathrm{~mL})$ were added under argon. The Schlenk tube was sealed with a Teflon valve and the reaction mixture was stirred at $110^{\circ} \mathrm{C}$ for $24 \mathrm{~h}$ in a preheated oil bath. The resulting dark purple-gray suspension was allowed to reach room temperature, transferred to a solution of $30 \%$ aq $\mathrm{NH}_{3}(5 \mathrm{~mL})$ in water $(20 \mathrm{~mL})$, and extracted with $\mathrm{CH}_{2} \mathrm{Cl}_{2}(3 \times 15 \mathrm{~mL})$. The combined organic layers were dried $\left(\mathrm{Na}_{2} \mathrm{SO}_{4}\right)$ and concentrated. NMR analysis of the crude product indicated $>99 \%$ conversion of the aryl bromide with $\sim 90 \%$ formation of the unexpanded cis- $N$-[2-(2-benzylamino)ethylphenyl]-3isopropyl-4-phenyl-2-azetidinone, $\sim 3 \%$ yield of $N$-benzylindoline, and only $\sim 2 \%$ yield of the desired 5-benzyl-3-isopropyl-2-phenyl-1,2,3,5,6,7-hexahydrobenzo[f][1,5]diazonin-4-one. The crude product mixture was dissolved in dioxane $(10 \mathrm{~mL})$ and, using a syringe, was transferred to a Schlenk tube filled with argon and capped with a rubber septum. Acetic acid $(0.58 \mathrm{~mL}, 10$ $\mathrm{mmol})$ and $\mathrm{Et}_{3} \mathrm{~N}(1.4 \mathrm{~mL}, 10 \mathrm{mmol})$ were added to the Schlenk tube, the rubber septum was replaced with a Teflon valve, and the sealed Schlenk tube was placed in an oil bath preheated to $110^{\circ} \mathrm{C}$. After stirring at $110^{\circ} \mathrm{C}$ for $23 \mathrm{~h}$, the resulting tan solution was allowed to reach room temperature, poured into $1 \mathrm{M}$ aq $\mathrm{Na}_{2} \mathrm{CO}_{3}(50 \mathrm{~mL})$, and extracted with $\mathrm{CH}_{2} \mathrm{Cl}_{2}(3 \times 30 \mathrm{~mL})$. The combined organic layers were dried $\left(\mathrm{Na}_{2} \mathrm{SO}_{4}\right)$, concentrated, and the residue was purified by column chromatography on silica gel (hexane-ethyl acetate 4:1). The product was recrystallized

\footnotetext{
${ }^{4}$ Prepared from an ester enolate and $N$-silylimine according to: Ha, D.-C.; Hart, D. J.; Yang, T.-K. J. Am. Chem. Soc. 1984, 106, 4819.

${ }^{5}$ Mori, M.; Chiba, K.; Ban, Y. J. Org. Chem. 1978, 43, 1684.
} 
from hot hexane $(\sim 5 \mathrm{~mL})$ to provide the desired cis-5-benzyl-3-isopropyl-2-phenyl-1,2,3,5,6,7hexahydrobenzo[f][1,5]diazonin-4-one (351 mg, 88\% yield) as colorless cubes. Mp 108-111 ${ }^{\circ} \mathrm{C}$. ${ }^{1} \mathrm{H}$ NMR $\left(400 \mathrm{MHz}, \mathrm{CDCl}_{3}\right): \delta$ 7.40-7.20 $(\mathrm{m}, 11 \mathrm{H}), 7.15(\mathrm{~d}, J=7.6 \mathrm{~Hz}, 1 \mathrm{H}), 7.03(\mathrm{~d}, J=\mathrm{Hz}$, $1 \mathrm{H}), 6.96(\mathrm{t}, J=7.6 \mathrm{~Hz}, 1 \mathrm{H}), 5.33(\mathrm{~d}, J=14.4 \mathrm{~Hz}, 1 \mathrm{H}), 4.70(\mathrm{~s}, 1 \mathrm{H}), 4.18(\mathrm{~d}, J=14.4 \mathrm{~Hz}, 1 \mathrm{H})$, 3.62-3.45 (m, 3H), $3.10(\mathrm{dd}, J=15.5,7.0 \mathrm{~Hz}, 1 \mathrm{H}), 2.78(\mathrm{dd}, J=15.5,8.2 \mathrm{~Hz}, 1 \mathrm{H}), 2.69(\mathrm{dd}, J=$ $10.6,4.0 \mathrm{~Hz}, 1 \mathrm{H}), 2.00-1.86(\mathrm{~m}, 1 \mathrm{H}), 1.01(\mathrm{~d}, J=6.5 \mathrm{~Hz}, 3 \mathrm{H}), 0.77(\mathrm{~d}, J=6.5 \mathrm{~Hz}, 3 \mathrm{H}) .{ }^{13} \mathrm{C}$ NMR $\left(100 \mathrm{MHz}, \mathrm{CDCl}_{3}\right): \delta 171.8,146.6,139.7,137.6,134.1,130.4,128.7,128.5,128.3,127.6$, 127.4, 127.32, 127.26, 123.4, 123.0, 66.3, 53.3, 50.1, 48.2, 34.2, 27.1, 21.9, 20.4. IR (neat, $\mathrm{cm}^{-}$ $\left.{ }^{1}\right)$ : 3368, 1637, 1496, 1447, 757, 731, 699. Anal. Calcd for $\mathrm{C}_{27} \mathrm{H}_{30} \mathrm{~N}_{2} \mathrm{O}: \mathrm{C}, 81.37$; H, 7.59. Found: C, 81.38; H, 7.89 .

Crystal structure for cis-5-Benzyl-3-isopropyl-2-phenyl-1,2,3,5,6,7-hexahydrobenzo[ $f][1,5]$ diazonin-4-one (Table 3, entry 3). 


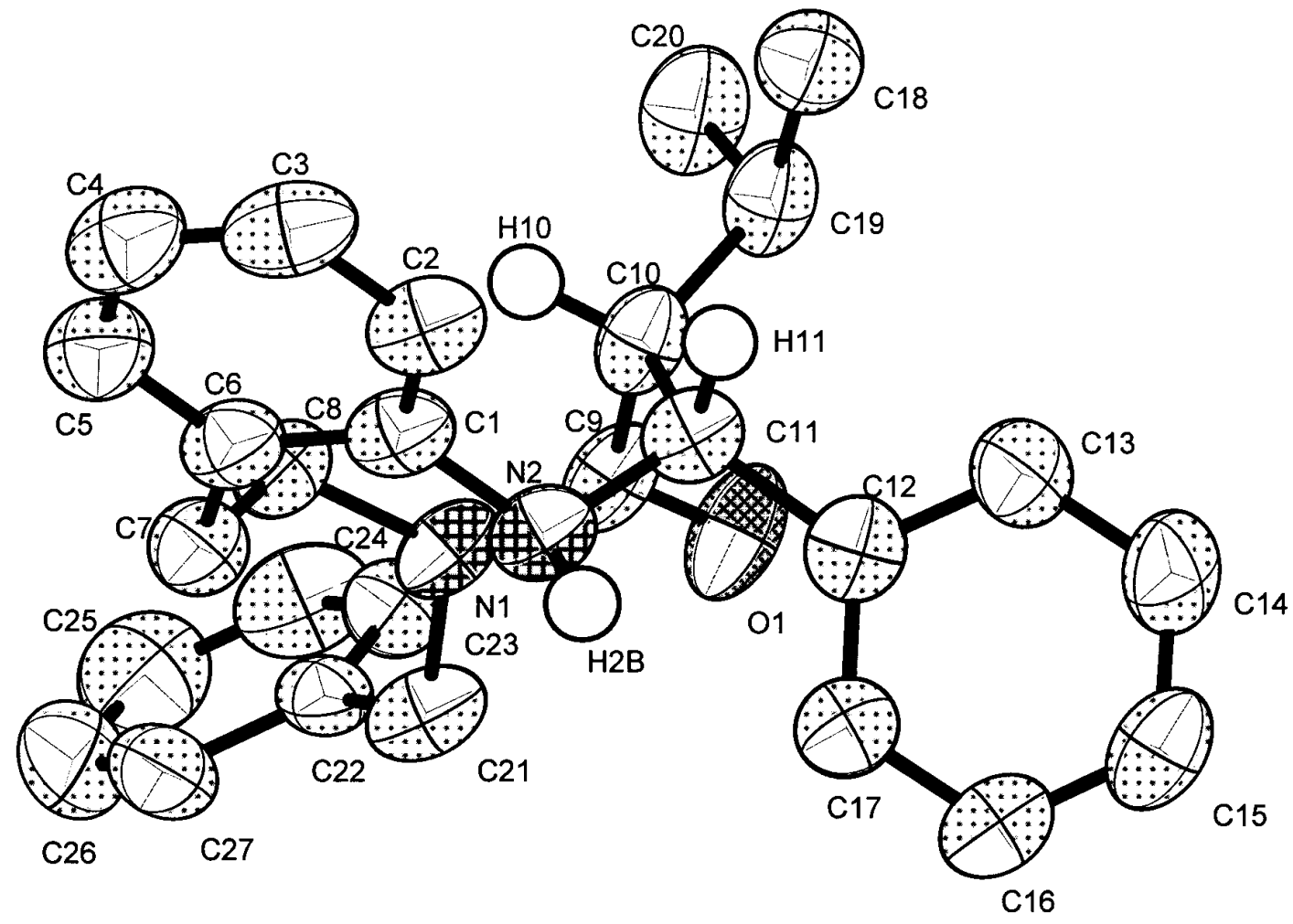

Table 1. Crystal data and structure refinement for XXXX.

Identification code

Empirical formula

Formula weight

Temperature

Wavelength

Crystal system

Space group

Unit cell dimensions

Volume

$\mathrm{Z}$

Density (calculated)

Absorption coefficient

$\mathrm{F}(000)$
XXXX

$\mathrm{C}_{27} \mathrm{H}_{30} \mathrm{~N}_{2} \mathrm{O}$

398.53

194(2) K

$0.71073 \AA$

Rhombohedral

R-3

$\mathrm{a}=28.661(2) \AA \quad \mathrm{a}=90^{\circ}$.

$\mathrm{b}=28.661(2) \AA$

$\mathrm{b}=90^{\circ}$.

$\mathrm{c}=14.6656(17) \AA$

$\mathrm{g}=120^{\circ}$.

$$
\text { 10433.2(17) } \AA^{3}
$$

18

$1.142 \mathrm{Mg} / \mathrm{m}^{3}$

$0.069 \mathrm{~mm}^{-1}$

3852 
Crystal size

Theta range for data collection

Index ranges

Reflections collected

Independent reflections

Completeness to theta $=23.32^{\circ}$

Absorption correction

Refinement method

Data / restraints / parameters

Goodness-of-fit on $\mathrm{F}^{2}$

Final R indices [I $>2 \operatorname{sigma}(\mathrm{I})]$

$\mathrm{R}$ indices (all data)

Largest diff. peak and hole
$0.48 \times 0.41 \times 0.39 \mathrm{~mm}^{3}$

1.42 to $23.32^{\circ}$.

$-31<=\mathrm{h}<=17,-31<=\mathrm{k}<=31,-16<=\mathrm{l}<=15$

16033

$3360[\mathrm{R}(\mathrm{int})=0.0470]$

$100.0 \%$

SADABS

Full-matrix least-squares on $\mathrm{F}^{2}$

3360 / 0 / 273

1.140

$\mathrm{R} 1=0.0963, \mathrm{wR} 2=0.2802$

$\mathrm{R} 1=0.1146, \mathrm{wR} 2=0.2952$

1.268 and -0.403 e. $\AA^{-3}$

Table 2. Atomic coordinates $\left(\mathrm{x} 10^{4}\right)$ and equivalent isotropic displacement parameters $\left(\AA^{2} \mathrm{X}\right.$ $10^{3}$ ) for XXXX. U(eq) is defined as one third of the trace of the orthogonalized $\mathrm{U}^{\mathrm{ij}}$ tensor.

\begin{tabular}{lrrrr}
\hline & $\mathrm{x}$ & $\mathrm{y}$ & $\mathrm{z}$ & $\mathrm{U}(\mathrm{eq})$ \\
\hline $\mathrm{C}(25)$ & & & & \\
$\mathrm{C}(18)$ & $-1556(2)$ & $3813(2)$ & $3053(6)$ & $94(2)$ \\
$\mathrm{O}(1)$ & $1513(2)$ & $5202(2)$ & $-568(3)$ & $66(1)$ \\
$\mathrm{N}(1)$ & $136(1)$ & $3804(1)$ & $596(2)$ & $72(1)$ \\
$\mathrm{N}(2)$ & $289(1)$ & $4183(1)$ & $1998(3)$ & $54(1)$ \\
$\mathrm{C}(12)$ & $1472(1)$ & $4396(1)$ & $1954(2)$ & $51(1)$ \\
$\mathrm{C}(1)$ & $1253(2)$ & $3886(2)$ & $512(3)$ & $50(1)$ \\
$\mathrm{C}(9)$ & $1750(2)$ & $4901(2)$ & $2412(3)$ & $51(1)$ \\
$\mathrm{C}(10)$ & $428(2)$ & $4177(2)$ & $1110(3)$ & $54(1)$ \\
$\mathrm{C}(11)$ & $980(2)$ & $4611(2)$ & $784(3)$ & $52(1)$ \\
$\mathrm{C}(2)$ & $1393(2)$ & $4416(2)$ & $974(3)$ & $49(1)$ \\
$\mathrm{C}(6)$ & $2276(2)$ & $5261(2)$ & $2183(3)$ & $59(1)$ \\
$\mathrm{C}(22)$ & $1495(2)$ & $5030(2)$ & $3107(3)$ & $55(1)$ \\
$\mathrm{C}(17)$ & $-644(2)$ & $3752(2)$ & $2631(3)$ & $48(1)$ \\
$\mathrm{C}(8)$ & $1033(2)$ & $3405(2)$ & $980(3)$ & $57(1)$ \\
$\mathrm{C}(23)$ & $518(2)$ & $4658(2)$ & $2601(3)$ & $54(1)$ \\
& $-950(2)$ & $3797(2)$ & $1962(3)$ & $62(1)$
\end{tabular}




$\begin{array}{lrrrr}\mathrm{C}(19) & 963(2) & 4782(2) & -206(3) & 59(1) \\ \mathrm{C}(13) & 1350(2) & 3875(2) & -415(3) & 63(1) \\ \mathrm{C}(5) & 1795(2) & 5518(2) & 3550(3) & 66(1) \\ \mathrm{C}(7) & 903(2) & 4676(2) & 3339(3) & 59(1) \\ \mathrm{C}(3) & 2562(2) & 5751(2) & 2630(4) & 70(1) \\ \mathrm{C}(21) & -167(2) & 3695(2) & 2396(3) & 64(1) \\ \mathrm{C}(4) & 2318(2) & 5880(2) & 3311(4) & 70(1) \\ \mathrm{C}(27) & -795(2) & 3744(2) & 3523(3) & 73(2) \\ \mathrm{C}(15) & 1006(2) & 2931(2) & -377(4) & 68(1) \\ \mathrm{C}(14) & 1218(2) & 3400(2) & -857(4) & 71(1) \\ \mathrm{C}(16) & 917(2) & 2937(2) & 543(4) & 67(1) \\ \mathrm{C}(20) & 576(2) & 5000(2) & -254(4) & 76(2) \\ \mathrm{C}(24) & -1414(2) & 3819(2) & 2179(5) & 80(2) \\ \mathrm{C}(26) & -1259(3) & 3775(2) & 3726(5) & 99(2)\end{array}$

Table 3. Bond lengths $[\AA]$ and angles $\left[{ }^{\circ}\right]$ for $\mathrm{XXXX}$.

\begin{tabular}{ll}
\hline $\mathrm{C}(25)-\mathrm{C}(24)$ & $1.342(9)$ \\
$\mathrm{C}(25)-\mathrm{C}(26)$ & $1.344(9)$ \\
$\mathrm{C}(18)-\mathrm{C}(19)$ & $1.522(7)$ \\
$\mathrm{O}(1)-\mathrm{C}(9)$ & $1.232(5)$ \\
$\mathrm{N}(1)-\mathrm{C}(9)$ & $1.365(6)$ \\
$\mathrm{N}(1)-\mathrm{C}(8)$ & $1.473(5)$ \\
$\mathrm{N}(1)-\mathrm{C}(21)$ & $1.475(6)$ \\
$\mathrm{N}(2)-\mathrm{C}(1)$ & $1.424(5)$ \\
$\mathrm{N}(2)-\mathrm{C}(11)$ & $1.460(5)$ \\
$\mathrm{C}(12)-\mathrm{C}(17)$ & $1.378(6)$ \\
$\mathrm{C}(12)-\mathrm{C}(13)$ & $1.391(6)$ \\
$\mathrm{C}(12)-\mathrm{C}(11)$ & $1.522(6)$ \\
$\mathrm{C}(1)-\mathrm{C}(2)$ & $1.377(6)$ \\
$\mathrm{C}(1)-\mathrm{C}(6)$ & $1.407(6)$ \\
$\mathrm{C}(9)-\mathrm{C}(10)$ & $1.519(6)$ \\
$\mathrm{C}(10)-\mathrm{C}(19)$ & $1.542(6)$ \\
$\mathrm{C}(10)-\mathrm{C}(11)$ & $1.567(5)$
\end{tabular}




\begin{tabular}{|c|c|}
\hline$C(2)-C(3)$ & $1.385(6)$ \\
\hline$C(6)-C(5)$ & $1.383(6)$ \\
\hline$C(6)-C(7)$ & $1.517(6)$ \\
\hline$C(22)-C(23)$ & $1.364(6)$ \\
\hline$C(22)-C(27)$ & $1.374(6)$ \\
\hline$C(22)-C(21)$ & $1.495(6)$ \\
\hline$C(17)-C(16)$ & $1.369(6)$ \\
\hline$C(8)-C(7)$ & $1.529(6)$ \\
\hline$C(23)-C(24)$ & $1.402(7)$ \\
\hline$C(19)-C(20)$ & $1.522(6)$ \\
\hline$C(13)-C(14)$ & $1.380(7)$ \\
\hline$C(5)-C(4)$ & $1.375(7)$ \\
\hline$C(3)-C(4)$ & $1.374(7)$ \\
\hline$C(27)-C(26)$ & $1.409(9)$ \\
\hline$C(15)-C(14)$ & $1.361(7)$ \\
\hline$C(15)-C(16)$ & $1.376(7)$ \\
\hline$C(24)-C(25)-C(26)$ & $120.1(6)$ \\
\hline $\mathrm{C}(9)-\mathrm{N}(1)-\mathrm{C}(8)$ & $125.9(4)$ \\
\hline $\mathrm{C}(9)-\mathrm{N}(1)-\mathrm{C}(21)$ & $119.5(4)$ \\
\hline $\mathrm{C}(8)-\mathrm{N}(1)-\mathrm{C}(21)$ & $114.3(4)$ \\
\hline $\mathrm{C}(1)-\mathrm{N}(2)-\mathrm{C}(11)$ & $116.3(3)$ \\
\hline$C(17)-C(12)-C(13)$ & $117.4(4)$ \\
\hline $\mathrm{C}(17)-\mathrm{C}(12)-\mathrm{C}(11)$ & $122.5(4)$ \\
\hline$C(13)-C(12)-C(11)$ & $120.1(4)$ \\
\hline $\mathrm{C}(2)-\mathrm{C}(1)-\mathrm{C}(6)$ & $119.9(4)$ \\
\hline $\mathrm{C}(2)-\mathrm{C}(1)-\mathrm{N}(2)$ & $119.4(4)$ \\
\hline $\mathrm{C}(6)-\mathrm{C}(1)-\mathrm{N}(2)$ & $120.6(4)$ \\
\hline $\mathrm{O}(1)-\mathrm{C}(9)-\mathrm{N}(1)$ & $121.2(4)$ \\
\hline $\mathrm{O}(1)-\mathrm{C}(9)-\mathrm{C}(10)$ & $119.8(4)$ \\
\hline $\mathrm{N}(1)-\mathrm{C}(9)-\mathrm{C}(10)$ & $118.8(4)$ \\
\hline $\mathrm{C}(9)-\mathrm{C}(10)-\mathrm{C}(19)$ & $111.8(3)$ \\
\hline$C(9)-C(10)-C(11)$ & $108.3(3)$ \\
\hline$C(19)-C(10)-C(11)$ & $115.5(3)$ \\
\hline $\mathrm{N}(2)-\mathrm{C}(11)-\mathrm{C}(12)$ & $111.6(3)$ \\
\hline $\mathrm{N}(2)-\mathrm{C}(11)-\mathrm{C}(10)$ & $110.4(3)$ \\
\hline
\end{tabular}




$\begin{array}{ll}\mathrm{C}(12)-\mathrm{C}(11)-\mathrm{C}(10) & 114.0(3) \\ \mathrm{C}(1)-\mathrm{C}(2)-\mathrm{C}(3) & 121.0(5) \\ \mathrm{C}(5)-\mathrm{C}(6)-\mathrm{C}(1) & 117.6(4) \\ \mathrm{C}(5)-\mathrm{C}(6)-\mathrm{C}(7) & 119.6(4) \\ \mathrm{C}(1)-\mathrm{C}(6)-\mathrm{C}(7) & 122.7(4) \\ \mathrm{C}(23)-\mathrm{C}(22)-\mathrm{C}(27) & 118.3(5) \\ \mathrm{C}(23)-\mathrm{C}(22)-\mathrm{C}(21) & 120.6(4) \\ \mathrm{C}(27)-\mathrm{C}(22)-\mathrm{C}(21) & 121.0(4) \\ \mathrm{C}(16)-\mathrm{C}(17)-\mathrm{C}(12) & 120.9(4) \\ \mathrm{N}(1)-\mathrm{C}(8)-\mathrm{C}(7) & 116.0(3) \\ \mathrm{C}(22)-\mathrm{C}(23)-\mathrm{C}(24) & 120.8(5) \\ \mathrm{C}(20)-\mathrm{C}(19)-\mathrm{C}(18) & 109.8(4) \\ \mathrm{C}(20)-\mathrm{C}(19)-\mathrm{C}(10) & 108.6(4) \\ \mathrm{C}(18)-\mathrm{C}(19)-\mathrm{C}(10) & 113.3(3) \\ \mathrm{C}(14)-\mathrm{C}(13)-\mathrm{C}(12) & 121.5(5) \\ \mathrm{C}(4)-\mathrm{C}(5)-\mathrm{C}(6) & 122.4(5) \\ \mathrm{C}(6)-\mathrm{C}(7)-\mathrm{C}(8) & 114.2(4) \\ \mathrm{C}(4)-\mathrm{C}(3)-\mathrm{C}(2) & 119.6(5) \\ \mathrm{N}(1)-\mathrm{C}(21)-\mathrm{C}(22) & 114.3(3) \\ \mathrm{C}(3)-\mathrm{C}(4)-\mathrm{C}(5) & 119.5(5) \\ \mathrm{C}(22)-\mathrm{C}(27)-\mathrm{C}(26) & 119.9(5) \\ \mathrm{C}(14)-\mathrm{C}(15)-\mathrm{C}(16) & 119.3(5) \\ \mathrm{C}(15)-\mathrm{C}(14)-\mathrm{C}(13) & 119.9(5) \\ \mathrm{C}(17)-\mathrm{C}(16)-\mathrm{C}(15) & 121.0(5) \\ \mathrm{C}(25)-\mathrm{C}(24)-\mathrm{C}(23) & 120.4(6) \\ \mathrm{C}(25)-\mathrm{C}(26)-\mathrm{C}(27) & 120.5(5) \\ & \end{array}$

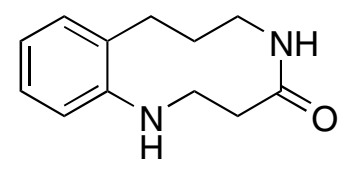

2,3,5,6,7,8-Hexahydro-1H-benzo[f][1,5]diazecin-4-one (Table 3, entry 4). A Schlenk tube was charged with $\mathrm{CuI}$ (9.6 mg, $0.050 \mathrm{mmol}, 5.0 \mathrm{~mol} \%$ ), 2-azetidinone (86 mg, $1.21 \mathrm{mmol}$ ), $\mathrm{K}_{2} \mathrm{CO}_{3}(280 \mathrm{mg}, 2.03 \mathrm{mmol})$, evacuated and backfilled with argon. 3-(2bromophenyl)propylamine ${ }^{6}(160 \mu \mathrm{L}, 1.00 \mathrm{mmol}), N, N^{\prime}$-dimethylethylenediamine $(11 \mu \mathrm{L}, 0.10$

\footnotetext{
${ }^{6}$ Wolfe, J. P.; Rennels, R. A.; Buchwald, S. L. Tetrahedron, 1996, 52, 7525.
} 
mmol, $10 \mathrm{~mol} \%)$ and toluene $(1.0 \mathrm{~mL})$ were added under argon. The Schlenk tube was sealed with a Teflon valve and the reaction mixture was stirred at $110{ }^{\circ} \mathrm{C}$ for $23 \mathrm{~h}$ in a preheated oil bath. The resulting tan suspension was allowed to reach room temperature, transferred to a solution of $30 \%$ aq $\mathrm{NH}_{3}(5 \mathrm{~mL})$ in water $(10 \mathrm{~mL})$, and extracted with $\mathrm{CH}_{2} \mathrm{Cl}_{2}(3 \times 15 \mathrm{~mL})$. GC analysis of the extract indicated $>99 \%$ conversion of the aryl bromide with $\sim 13 \%$ yield of 1,2,3,4-tetrahydroquinoline. The combined organic layers were dried $\left(\mathrm{Na}_{2} \mathrm{SO}_{4}\right)$ and concentrated. The crude product mixture was dissolved in THF (10 mL) and, using a syringe, was transferred to a Schlenk tube filled with argon and capped with a rubber septum. Acetic acid (115 $\mu \mathrm{L}, 2.01 \mathrm{mmol})$ was added to the Schlenk tube, the rubber septum was replaced with a Teflon valve, and the sealed Schlenk tube was placed in an oil bath preheated to $110{ }^{\circ} \mathrm{C}$. After stirring at $60{ }^{\circ} \mathrm{C}$ for $4 \mathrm{~h}$, the resulting pale yellow solution was allowed to reach room temperature, poured into a solution of $30 \%$ aq $\mathrm{NH}_{3}(10 \mathrm{~mL})$ in water $(20 \mathrm{~mL})$, and extracted with $\mathrm{CH}_{2} \mathrm{Cl}_{2}(3 \times 20 \mathrm{~mL})$. The combined organic layers were dried $\left(\mathrm{Na}_{2} \mathrm{SO}_{4}\right)$, concentrated, and the residue was purified by column chromatography on silica gel $\left(\mathrm{CH}_{2} \mathrm{Cl}_{2}-\mathrm{MeOH} 20: 1\right)$ to provide the desired product (140 mg, 69\% yield) as a white solid. Mp 161-163 ${ }^{\circ} \mathrm{C}$. The ${ }^{1} \mathrm{H}$ and ${ }^{13} \mathrm{C} \mathrm{NMR}$ spectra displayed two sets of signals due to rotamers of the cyclic amide in a 2:3 ratio. ${ }^{1} \mathrm{H}$ NMR $\left(400 \mathrm{MHz}, \mathrm{CDCl}_{3}\right): \delta$ 7.19-7.06 (m, 2H), $6.97(\mathrm{~d}, \mathrm{~J}=8.0 \mathrm{~Hz}, 0.4 \mathrm{H}), 6.94(\mathrm{~d}, \mathrm{~J}=8.0 \mathrm{~Hz}, 0.6 \mathrm{H})$, 6.87-6.79 (m, 1H), 5.78 (br s, 0.4H), 4.91 (br s, 0.6 H), 4.00-3.86 (m, 0.6H), 3.80-3.50 (m, 3.4 H), 3.15-2.90 (br m, 1H), 2.80-2.64 (br m, 0.8H), 2.60-2.45 (br m, 1.8H), 2.28 (t, J = 5.8 Hz, 1.2 $\mathrm{Hz}$ ), 2.30-1.82 (br m, 1.8H), 1.74-1.62 (br m, 0.4H). $\left.{ }^{13} \mathrm{C} \mathrm{NMR} \mathrm{(100} \mathrm{MHz}, \mathrm{CDCl}_{3}\right): \delta 176.2$, $173.5,147.2$, 145.6, 132.5, 131.6, 130.8, 129.0, 128.4, 127.8, 121.5, 121.0, 118.2, 117.2, 45.8, 42.5, 40.9, 40.4, 37.2, 32.4, 32.3, 31.1, 26.9, 24.3. IR (neat, $\mathrm{cm}^{-1}$ ): 3372, 3291, 1652, 1583, 1505, 1457, 743. Anal. Calcd for $\mathrm{C}_{12} \mathrm{H}_{16} \mathrm{~N}_{2} \mathrm{O}: \mathrm{C}, 70.56 ; \mathrm{H}, 7.89$. Found: C, 70.41; H, 8.03.

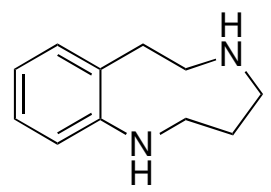

2,3,4,5,6,7-hexahydrobenzo[f][1,5]diazonine. A $25 \mathrm{~mL}$ round bottom flask was filled with argon and charged with 1,2,3,5,6,7-hexahydrobenzo[f][1,5]diazonin-4-one (85 mg, $0.48 \mathrm{mmol}$ ). The flask was sealed with a septum and $1.0 \mathrm{M} \mathrm{BH}_{3}$ in THF (4.5 mL, $\left.4.5 \mathrm{mmol}\right)$ was added under argon. The resulting colorless solution was stirred at room temperature for $20 \mathrm{~h}$, carefully 
quenched with $10 \%$ aq $\mathrm{HCl}(10 \mathrm{~mL}$; Caution: exothermic evolution of hydrogen gas!), and stirred at room temperature for an additional $3 \mathrm{~h}$. The reaction mixture was poured into $20 \%$ aq $\mathrm{NaOH}(20 \mathrm{~mL})$ and extracted with $\mathrm{CH}_{2} \mathrm{Cl}_{2}(3 \times 20 \mathrm{~mL})$. The combined organic layers were dried $\left(\mathrm{Na}_{2} \mathrm{SO}_{4}\right)$, concentrated, and the residue was purified by column chromatography on silica gel $\left(\mathrm{CH}_{2} \mathrm{Cl}_{2}\right.$ (saturated with $30 \%$ aq $\left.\mathrm{NH}_{3}\right)-\mathrm{CH}_{2} \mathrm{Cl}_{2}-\mathrm{MeOH}$ 10:10:1) to provide the desired product as a colorless oil (69 mg, 88\% yield). ${ }^{1} \mathrm{H}$ NMR $\left(400 \mathrm{MHz}, \mathrm{CDCl}_{3}\right): \delta 7.14(\mathrm{td}, \mathrm{J}=7.8,1.4 \mathrm{~Hz}, 1 \mathrm{H})$, $7.00(\mathrm{dd}, \mathrm{J}=7.8,1.4 \mathrm{~Hz}, 1 \mathrm{H}), 6.95(\mathrm{dd}, \mathrm{J}=7.8,1.4 \mathrm{~Hz}, 1 \mathrm{H}), 6.80(\mathrm{td}, \mathrm{J}=7.8,1.4 \mathrm{~Hz}, 1 \mathrm{H}), 3.43-$ $3.39(\mathrm{~m}, 2 \mathrm{H}), 2.92(\mathrm{t}, \mathrm{J}=5.8 \mathrm{~Hz}, 2 \mathrm{H}), 2.88-2.83(\mathrm{~m}, 2 \mathrm{H}), 2.74-2.70(\mathrm{~m}, 2 \mathrm{H}), 1.36-1.29(\mathrm{~m}, 2 \mathrm{H})$. The $\mathrm{N}-\mathrm{H}$ protons appeared as extremely broad signals at the baseline of the ${ }^{1} \mathrm{H}$ NMR spectrum and could not be integrated accurately. ${ }^{13} \mathrm{C}$ NMR $\left(100 \mathrm{MHz}, \mathrm{CDCl}_{3}\right): \delta 149.4,134.8,130.2$, 127.4, 121.1, 120.5, 52.3, 50.1, 48.1, 39.2, 24.5. IR (neat, $\mathrm{cm}^{-1}$ ): 3288, 1585, 1511, 1481, 1448, 1132, 761, 742. HRMS-EI calcd for $\mathrm{C}_{11} \mathrm{H}_{16} \mathrm{~N}_{2}\left(\mathrm{M}^{+}\right), 176.1308$; found, 176.1315 . 